\title{
A study of the potential of hedgerow intercropping in semi- arid India using a two-way systematic design
}

\author{
M.R. RAO ${ }^{1}$, M.M. SHARMA ${ }^{2}$ and C.K. ONG ${ }^{2}$ \\ 'International Council for Research in Agroforestry (ICRAF), P.O. Box 30677, Nairobi, \\ Kenya \\ ${ }^{2}$ International Crops Research Institute for the Semi-Arid Tropics (ICRISAT), Patancheru \\ P.O. 502 324, A.P., India
}

Key words: Alley cropping, fodder, India, intercrops, Leucaena, pigeonpea, semi-arid tropics, sorghum

\begin{abstract}
The potential of hedgerow intercropping with Leucaena leucocephala was explored on vertic Inceptisols over 4 years at ICRISAT Center, Patancheru, India. The study was conducted using a systematic layout involving different alley widths ranging from 1.35 to $4.95 \mathrm{~m}$ and with varying distances between hedge and crops. The alleys were cropped with alternate rows of sorghum and pigeonpea. Hedges composed double Leucaena hedgerows $60 \mathrm{~cm}$ apart were periodically harvested for fodder. Sole crops of all components and a sorghum/pigeonpea intercrop were included in all four replications of the study.

Starting in the second year, Leucaena was progressively more competitive to annual crops, causing substantial yield reduction. Competition (primarily for moisture) was most severe in narrow alleys and was greatest on pigeonpea.

The growth of Leucaena was not sufficient to compensate for reduced crop yields. Land equivalent ratios (LERs) calculated on the basis of grain yield of crops and Leucaena fodder yields showed that hedgerow intercropping (HI) was advantageous over sole crops only during the first two years using wide alleys, but disadvantageous in the last two years. LERs calculated on the basis of total dry matter indicated only a small advantage for HI (13-17 percent) over sole crops in wider ( $>4 \mathrm{~m}$ ) alleys. Average returns per year from $\mathrm{HI}$ exceeded those of the most productive annual crop system (sorghum/pigeonpea intercropping) by 8 percent in $4.05 \mathrm{~m}$ alleys, and by 16 percent in $4.95 \mathrm{~m}$ alleys. Fodder production during the dry season was 40 percent of the annual total in these alley widths. Thus hedgerow intercropping at $4-5 \mathrm{~m}$ alley width is not very attractive for farmers in semi-arid India, which has 600 $700 \mathrm{~mm}$ of annual rainfall. There is a need to examine the potential of $\mathrm{HI}$ in wider alleys. The merits and limitations of the systematic design are discussed.
\end{abstract}

\section{Introduction}

Agroforestry systems are at least as complex as intercropping with annual crops. While some of the research methods employed in intercropping have relevance to agroforestry research, special field layouts and evaluation 
methods are required for the latter to attend to specific problems associated with perennial species. To develop any agroforestry system, one should work out the proportion of the perennials (number of trees), the proportion of the annual crop, and the spatial arrangement or the proximity at which both components can be planted. Quantification of tree/crop interface is the key to the understanding of competition between species and to the success of an agroforestry system [4]. Systematic designs have been in use in intercropping and horticultural crops for quantifying the yield-plant population/spacing relationships $[1,3,8,10]$. Some of the designs can be extended for the study of agroforestry systems [5]. In view of the large number of factors to be studied in these systems, the number of combinations can become too unwieldy to evaluate in conventional designs. Systematic designs despite their limitations have been proposed for agroforestry research because they minimize the requirement for field and experimental resources.

The potential of hedgerow intercropping (also known as alley cropping) for sustained crop yields by incorporating the prunings from hedges of perennials has been demonstrated in humid tropics [7]. This technology is now being studied extensively throughout tropics, though studies in semi-arid climates are limited. In the Indian semi-arid tropics green fodder is scarce during the 7 to 9 months of dry period. Inclusion of multipurpose perennials such as Leucaena, Gliricidia, and Sesbania sp. in the annual crop systems might help alleviate the fodder scarcity. During the dry season these perennials might also explore the residual moisture and nutrients beyond the reach of annual crops and produce extra dry matter. However the removal of prunings for fodder will deprive much of the potential benefit for soil fertility improvement. Since food crops are important for the subsistence farmers, any new agroforestry system will only be acceptable to them only if annual crop yields are not unduly affected by the perennial species.

Initial studies on alley cropping in the Indian semi-arid tropics have given conflicting results on its potential [9]. Most studies have used Leucaena leucocephala because of its good coppicing ability and high fodder value [2]. Agroforestry experiments were initiated at ICRISAT Center, Patancheru, India in 1984 to provide quantitative information on the productivity and resource use in hedgerow intercropping systems [6].

This paper describes an experimental field layout, designed particularly for studying hedgerow intercropping using Leucaena. We also discuss the potential of the system based on agronomic and economic results of the study for over four years. 


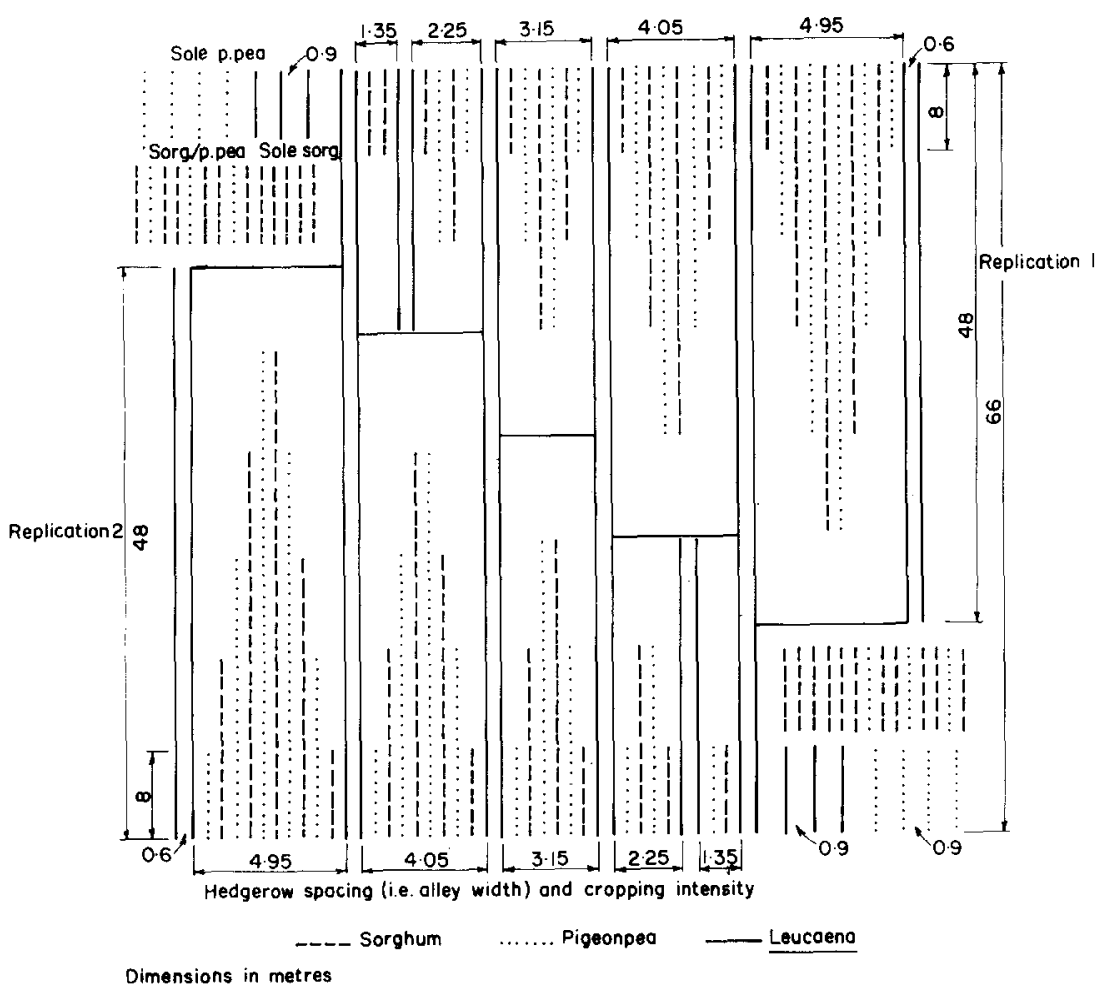

Fig. 1. Layout of 2-way systematic design for studying the hedgerow spacing and cropping intensity.

\section{Materials and methods}

\section{Experimental design}

The design was intended to give a range of spacings between hedges and concomitant changes in the proportion of annual crop. The spacing between Leucaena hedges (each hedge consisted of double Leucaena hedgerows spaced at $60 \mathrm{~cm}$ apart) varied from $1.35 \mathrm{~m}$ at one end of the plot to $4.95 \mathrm{~m}$ at the other end in steps of $0.9 \mathrm{~m}$. An intercrop of sorghum/pigeonpea in alternate row arrangement $45 \mathrm{~cm}$ was sown in the alleys. Thus, the proportion of Leucaena decreased as alley width increased from 1.35 to $4.95 \mathrm{~m}$ (i.e. change in horizontal direction). Within each alley width, the distance between Leucaena and annual crops was increased by omitting one row of the annual crop on either side of Leucaena hedge successively for every $8 \mathrm{~m}$ row length (i.e. change in vertical direction) until a fallow was obtained for that hedge spacing (Fig. 1). Sole crops of Leucaena (three rows at $0.9 \mathrm{~m}$ spacing), 
sorghum ( 6 rows at $45 \mathrm{~cm}$ spacing), and pigeonpea ( 4 rows at $0.9 \mathrm{~m}$ ), and sorghum/pigeonpea intercrop ( 8 rows in 2 sorghum: 1 pigeonpea arrangement) were located adjacent to the narrowest alley width. This arrangement covered one side of the diagonal of a $26.5 \mathrm{~m} \times 66 \mathrm{~m}$ block. A mirror image of this arrangement on the other side of the diagonal provided another replication. Thus, each block had two replications, and the block was repeated to provide a total of four replications. Sorghum/pigeonpea intercrop was sown every season $2-5 \mathrm{~m}$ width all around the block to minimize border effects on the outer hedges.

In the second year the sole crops were affected by adjacent Leucaena, therefore a thick sheet of polythene root barriers was installed by digging a trench between sole plots of Leucaena and pigeonpea, down to $50 \mathrm{~cm}$ depth.

\section{Crop and tree management}

The experiment was conducted on shallow black soils (Vertic Inceptisols) which had a profile depth of $40-45 \mathrm{~cm}$ of top soil and a variable murrum layer below. The site was low in available nitrogen but medium in available phosphorus and potassium, and has been cropped in the past 7-8 years alternating with sorghum and sorghum/pigeonpea intercrop.

Leucaena leucocephala (cv. K8) was established by direct seeding of scarified (with concentrated sulphuric acid) and pregerminated seeds on June 19, 1984 using higher than the required seed rate. The stand was thinned to $20 \mathrm{~cm}$ within-rows two weeks after emergence. Sorghum (cv. CSH.9) and pigeonpea (cv. ICP 1) were sown at a density of 150,000 and $50,000 \mathrm{plants} / \mathrm{ha}$ respectively in sole cropping and with additive populations in intercropping. The sorghum/pigeonpea intercrop, as the most appropriate and productive cropping system for these soils, provided the basis for comparison with the hedgerow intercrops. The area was fertilized with $100 \mathrm{~kg} / \mathrm{ha}$ of diammonium phosphate, broadcast and incorporated at the beginning of each season. Sorghum was top dressed with $42 \mathrm{~kg} \mathrm{~N} / \mathrm{ha}$ three weeks after sowing. Sorghum and Leucaena did not require any plant protection, but pigeonpea was sprayed once or twice with endosulphan against pod borer. In view of poor yields of pigeonpea in the second and third year, only sorghum was used in the alleys during the fourth year. The chronology of field operations and seasonal rainfall are given in Table 1.

Leucaena was harvested for the first time $5 \frac{1}{2}$ months after sowing by pruning at $75 \mathrm{~cm}$ height, but yield at this harvest was very small. Subsequent harvests were made at about 3 months interval depending on regrowth, usually four harvests per year once in the beginning of the rainy season, after sorghum harvest, and twice during the dry season. For each alley width 
Table 1. Chronology of field operations and rainfall during the study period

\begin{tabular}{|c|c|c|c|c|}
\hline Crop & $\begin{array}{l}\text { Year } 1 \\
1984-85^{\text {a }}\end{array}$ & $\begin{array}{l}\text { Year } 2 \\
1985-86\end{array}$ & $\begin{array}{l}\text { Year } 3 \\
1986-87\end{array}$ & $\begin{array}{l}\text { Year } 4 \\
1987-88\end{array}$ \\
\hline \multicolumn{5}{|l|}{ Leucaena } \\
\hline Seeding & Jun 19,84 & - & - & - \\
\hline Pruning & Nov 29,84 & Oct 10,85 & Jul 28, 86 & Jul 29,87 \\
\hline Pruning & Apr 04,85 & Jan 20,86 & Oct 15,86 & Nov 03,87 \\
\hline Pruning & Jul 17,85 & Apr 15,86 & Feb 25, 87 & Feb 04, 88 \\
\hline Pruning & - & Jun 10,86 & Jun 02,87 & May $26,88^{b}$ \\
\hline \multicolumn{5}{|l|}{ Annual Crops } \\
\hline Sowing & Jun 16,84 & Jun 12,85 & Jun 18,86 & Jun 08,88 \\
\hline $\begin{array}{l}\text { Sorghum } \\
\text { harvest }\end{array}$ & Oct 08,84 & Sep 23,85 & Oct 31,86 & Sep 26,87 \\
\hline $\begin{array}{l}\text { Pigeonpea } \\
\text { harvest }\end{array}$ & Jan 15,85 & Jan 13,86 & Jan 08,87 & Feb 19,88 \\
\hline \multicolumn{5}{|l|}{ Rainfall ( $\mathrm{mm}$ ) } \\
\hline Jun-Dec & 600 & 485 & 580 & 620 \\
\hline Annual total & 670 & 617 & 623 & 739 \\
\hline
\end{tabular}

a June 1-May 30.

b Final harvest of Leucaena.

treatment, crops and one row of Leucaena on either side of the alley were harvested from $6 \mathrm{~m}$ row length leaving one meter as head border on each end. The Leucaena prunings were separated into fodder and sticks (stems $>0.5 \mathrm{~cm}$ diameter) and weighed. Their dry weights were computed based on the moisture content determined at each harvest in a few sub-samples. Leucaena was finally removed after 4 years on May 26, 1988, when Leucaena trunks were also weighed. Grain yields, sorghum stover, pigeonpea stalks and haulms (husk after threshing) were also weighed each year for calculating their value in a final economic evaluation of the system.

\section{Analysis of results}

Though the analysis of variance is not valid for systematic designs, crop yields and Leucaena fodder and wood yields were analyzed as a randomized block design in order to have an approximate measure of experimental variability. The relationships of Leucaena yield - plant population, and hedgerow performance-space between hedge and annual crops were fitted with regression equations. The productivity of hedgerow intercropping was evaluated by calculating land equivalent ratios [LER, Willey, 1979] for each year using the highest yield of sole Leucaena and sole annual crops. Monetary returns of different hedgerow intercrop treatments were computed by 


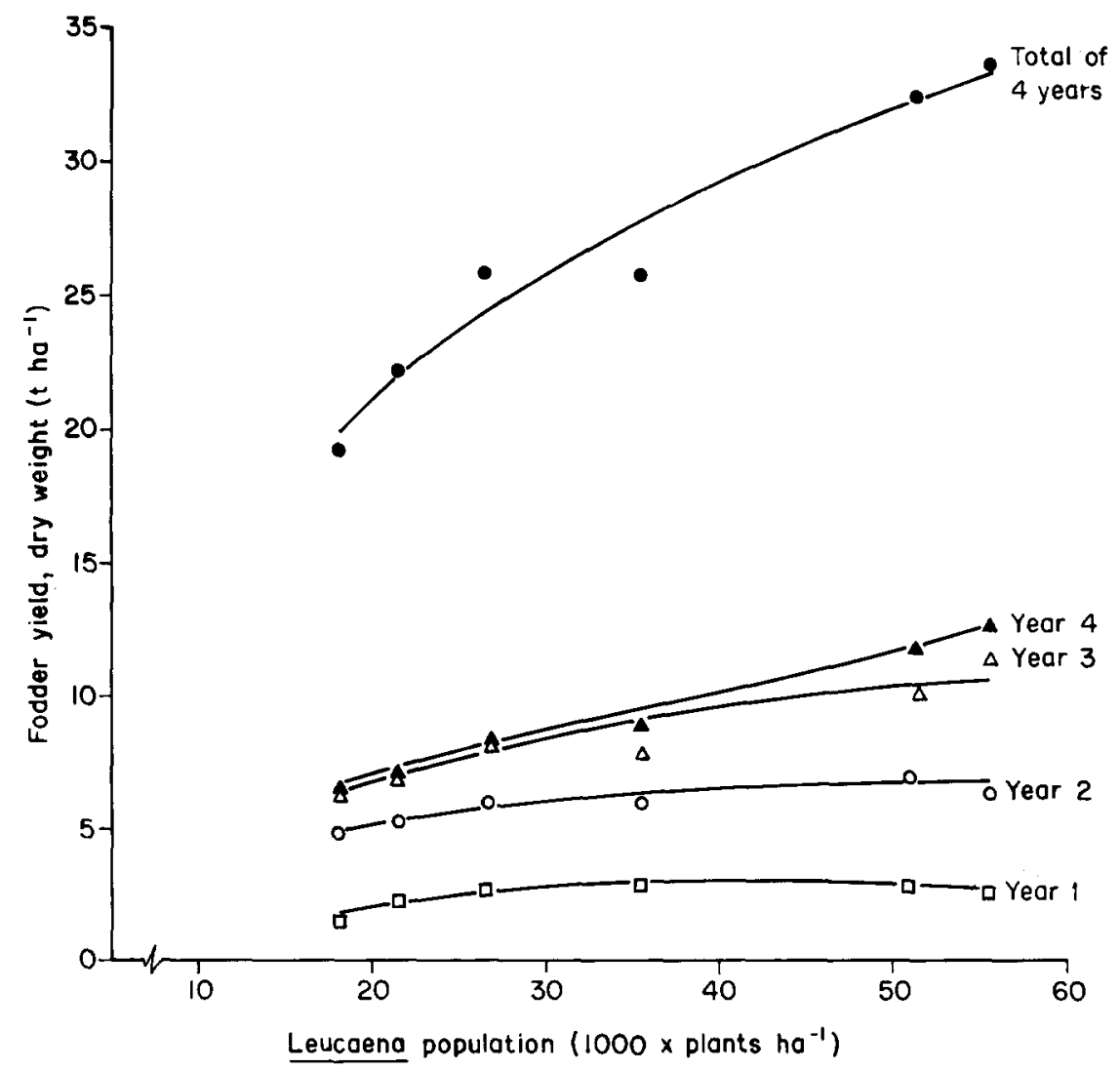

Fig. 2. Response of sole Leucaena to plant population in respect of fodder yield.

adding the economic values of all the harvested produce from each treatment based on the prevailing market values in each year and subtracting the costs of variable inputs (labour, seeds, fertilizer etc.) from the gross returns of the system.

\section{Results}

The direct seeded Leucaena established very well; though some seedling mortality was noted in the early stage due to soil insects, the use of higher than the required seed rate was sufficient. Sole Leucaena populations varied from 18,000 plants $/$ ha in $4.95 \mathrm{~m}$ hedge spacing to 55,555 plants $/$ ha in $0.9 \mathrm{~m}$ row spacing. It showed a progressively linear dry matter response to plant population over the years (Fig. 2). Response in the first year was limited to 27,000 plants/ha, 51,000 plants/ha in the second year, and up to 
Table 2. Yields of sorghum and pigeonpea intercropped between Leucaena hedges established at different spacings over a 4-year period at ICRISAT Center, India

\begin{tabular}{|c|c|c|c|c|c|c|}
\hline \multirow{2}{*}{$\begin{array}{l}\text { Alley width } \\
\text { or hedge } \\
\text { spacing } \\
\text { (m) }\end{array}$} & \multirow{2}{*}{$\begin{array}{l}\text { Gap between } \\
\text { hedge and } \\
\text { crops } \\
(\mathrm{cm})\end{array}$} & \multicolumn{2}{|l|}{ Year 1} & \multirow{2}{*}{$\begin{array}{l}\text { Year } 2 \\
\text { Sorghum }\end{array}$} & \multirow{2}{*}{$\begin{array}{l}\text { Year } 3 \\
\text { Sorghum }\end{array}$} & \multirow{2}{*}{$\begin{array}{l}\text { Year } 4 \\
\text { Sorghum }\end{array}$} \\
\hline & & Sorghum & Pigeonpea & & & \\
\hline 1.35 & 45 & 1240 & 730 & 220 & 30 & 260 \\
\hline \multirow[t]{2}{*}{2.25} & 45 & 1500 & 1045 & 875 & 360 & 830 \\
\hline & 90 & 1170 & 540 & 470 & 190 & 490 \\
\hline \multirow[t]{3}{*}{3.15} & 45 & 1245 & 855 & 1100 & 1365 & 1330 \\
\hline & 90 & 1495 & 725 & 870 & 730 & 1045 \\
\hline & 135 & 945 & 615 & 585 & 425 & 785 \\
\hline \multirow[t]{4}{*}{4.05} & 45 & 1450 & 1075 & 1385 & 1430 & 1945 \\
\hline & 90 & 1360 & 750 & 1175 & 1005 & 1540 \\
\hline & 135 & 1235 & 690 & 1005 & 750 & 1230 \\
\hline & 180 & 860 & 475 & 770 & 450 & 805 \\
\hline \multirow[t]{5}{*}{4.95} & 45 & 1750 & 875 & 1680 & 1470 & 2380 \\
\hline & 90 & 1530 & 785 & 1330 & 1325 & 2080 \\
\hline & 135 & 1240 & 685 & 1255 & 1065 & 1630 \\
\hline & 180 & 900 & 500 & 980 & 765 & 1250 \\
\hline & 225 & 540 & 395 & 610 & 425 & 750 \\
\hline $\mathrm{SE} \pm$ & & 171 & 151 & 127 & 65 & 156 \\
\hline Sorghum/pigeonpea & & 2690 & 745 & $2460 / 235^{*}$ & $3120 / 130^{*}$ & $3445 / 545^{*}$ \\
\hline Sole sorghum & & 3475 & - & 2605 & 5135 & 4735 \\
\hline Sole pigeonpea & & - & 1460 & 175 & 830 & 850 \\
\hline
\end{tabular}

* Pigeonpea yields.

$55.555 \mathrm{plants} / \mathrm{ha}$ in the last two years. Total yield over 4 years also showed a linear response with $1 / \mathrm{w}=0.555+0.202 \mathrm{x}(\mathrm{w}=$ yield per plant and $\mathrm{x}=$ plants $/ \mathrm{m}^{2}$ ) which explained 96 percent of the variation. However, yield increase beyond 51,000 plants was small indicating that no worthwhile responses might be observed higher than 55,555 plants/ha. Fodder yields increased over years from $2.8 \mathrm{t} / \mathrm{ha}$ in the first year to $12.83 \mathrm{t} / \mathrm{ha}$ in the fourth year.

In 1984 , sole sorghum yielded $3.47 \mathrm{t} / \mathrm{ha}$ and sole pigeonpea $1.46 \mathrm{t} / \mathrm{ha}$ of grain (Table 2). Annual crops were dominant over Leucaena in this first year; consequently, their yields were higher than expected for the proportional space occupied by them in hedgerow intercropping systems. For each alley width, Leucaena growth improved linearly with increasing distance between Leucaena and annual crops. The hedge yield per unit length was similar across different alley widths for the same hedge/crop interface distance. Obviously, the hedge/crop interaction was independent of hedge spacing in this first year. At the constant interface distance of $45 \mathrm{~cm}$, Leucaena yields decreased from 28 percent of sole Leucaena in $1.35 \mathrm{~m}$ alleys 
to 10 percent in $4.95 \mathrm{~m}$ alleys because of reduced Leucaena proportion in the system.

Low rainfall in 1985 reduced sole sorghum yields ( $2.61 \mathrm{t} / \mathrm{ha})$, and pigeonpea suffered from severe moisture stress in the postrainy season, producing only $175 \mathrm{~kg} / \mathrm{ha}$ in sole cropping and less than $85 \mathrm{~kg} / \mathrm{ha}$ in hedgerow intercropping (Table 2). Sorghum still gave higher than the expected yield at alley widths greater than $3.0 \mathrm{~m}$ but its yield was reduced due to the competition of Leucaena at closer alley widths. Leucaena was more competitive to annual crops than in the previous year. Though hedge yields in intercropping were lower than in sole system they were higher than expected for the relative space occupied by them. Hedges performed similarly across alley widths at hedge/crops interface distance of $45 \mathrm{~cm}$ but at larger distances hedge yields improved with wider alley width.

Though rainfall was less than normal in 1986, sole sorghum gave high yield ( $5.13 \mathrm{t} / \mathrm{ha})$ because of good rainfall distribution during the sorghum growing period. Pigeonpea experienced drought in the postrainy season resulting in a yield of $830 \mathrm{~kg} / \mathrm{ha}$ in sole cropping but only less than $75 \mathrm{~kg} / \mathrm{ha}$ in hedgerow intercropping. Leucaena yields increased greatly over those in the previous years, and individual hedge yields also increased with wider alleys. The tree was much more competitive than in earlier years leaving diminished sorghum yields in all treatments.

Only sorghum was sown in alleys in 1987 as pigeonpea performance was poor in hedgerow intercropping. Sorghum yields were slightly better than expected in the two wider alleys $(4.05 \mathrm{~m})$, but were reduced in closer alley widths due to the competition of Leucaena which became more dominant. Hedge performance increased as distance between hedge and annual crops increased from 45 to $135 \mathrm{~cm}$ (Fig. 3). Presumably, the roots of Leucaena had extended laterally beyond $135 \mathrm{~cm}$. Similar trend was noted in the two widest alleys where it was possible to examine large interface gap between Leucaena and annual crops.

\section{Land equivalent ratios}

LERs were calculated in two ways: based on i) economic products (dry weight of Leucaena fodder and grain yields of crops) and ii) total biomass over 4 years, using the highest sole crop and Leucaena yields as standard. However, as sole pigeonpea yield in second year was lower than intercropped pigeonpea yield, the latter was used in LER calculation in that year (see discussion).

In the first year, LERs of annual crops were much higher than expected (Fig. 4). So, though the Leucaena LERs were lower than expected, the total 


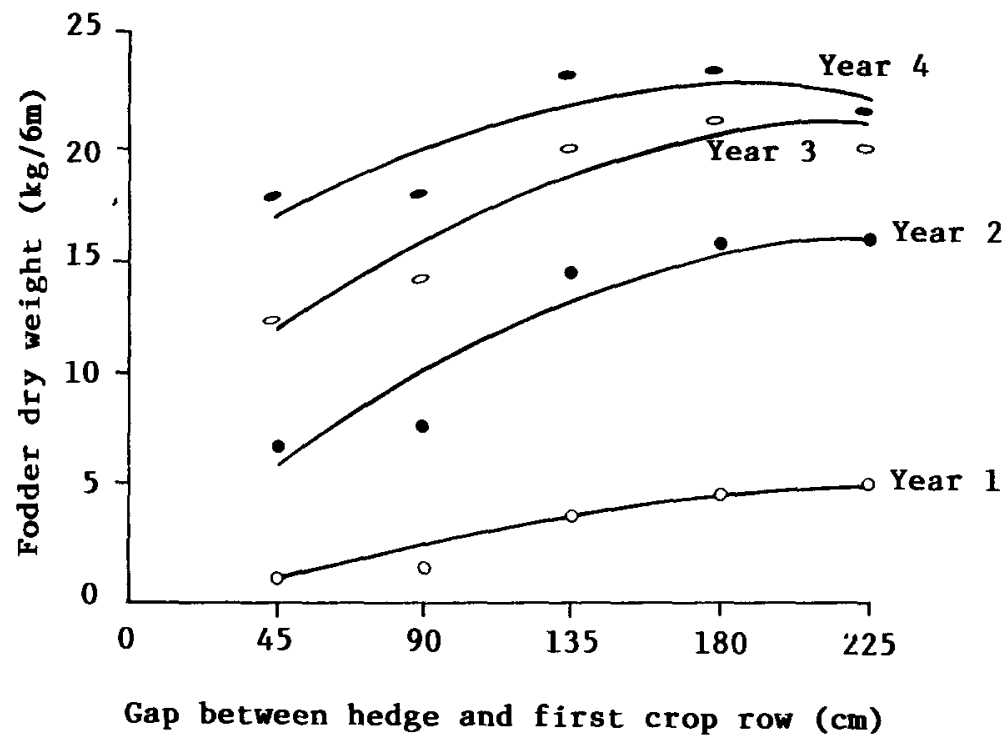

Fig. 3. Effect of first crop row distance on the fodder yield of hedgerow.

LERs were higher than 1.0 for all alley widths indicating the advantage of hedgerow intercropping over sole crops. The highest advantage of 44 percent was recorded for $2.25 \mathrm{~m}$ alley width. Within each alley width, maximum LER was achieved where the hedge/crops interface was $45 \mathrm{~cm}$ and LER declined with increasing gap (i.e. decreased proportion of annual crops).

In the second year LERs increased with greater alley width. Nevertheless, they were higher than 1.0 only in the two wider alley widths (1.23 and 1.32 at $45 \mathrm{~cm}$ crop/hedge spacing). Highest values were noted where the gap between crop and hedge was $135 \mathrm{~cm}$ primarily due to high pigeonpea LER which was the result of low and variable pigeonpea yields in this year.

LERs in the last two years were lower than 1.0 in all hedgerow treatments indicating lower productivity of this system compared with sole crops (Fig. 5). Leucaena LERs were higher than expected but the annual crop LERs, particularly of pigeonpea in the third year, were much lower than expected. LERs calculated on the basis of total dry matter of all the components indicated that hedgerow intercropping was disadvantageous at $1.35 \mathrm{~m}$, as good as the sole crops at $2.25 \mathrm{~m}$ and $3.15 \mathrm{~m}$ alley widths, and was slightly more productive (1216 percent) than sole crops at the two wider alley widths (Table 4).

\section{Economic returns}

In each alley width, highest returns were where the hedge/crop distance was $45 \mathrm{~cm}$. So, returns from all alley widths with $45 \mathrm{~cm}$ gap were compared with 


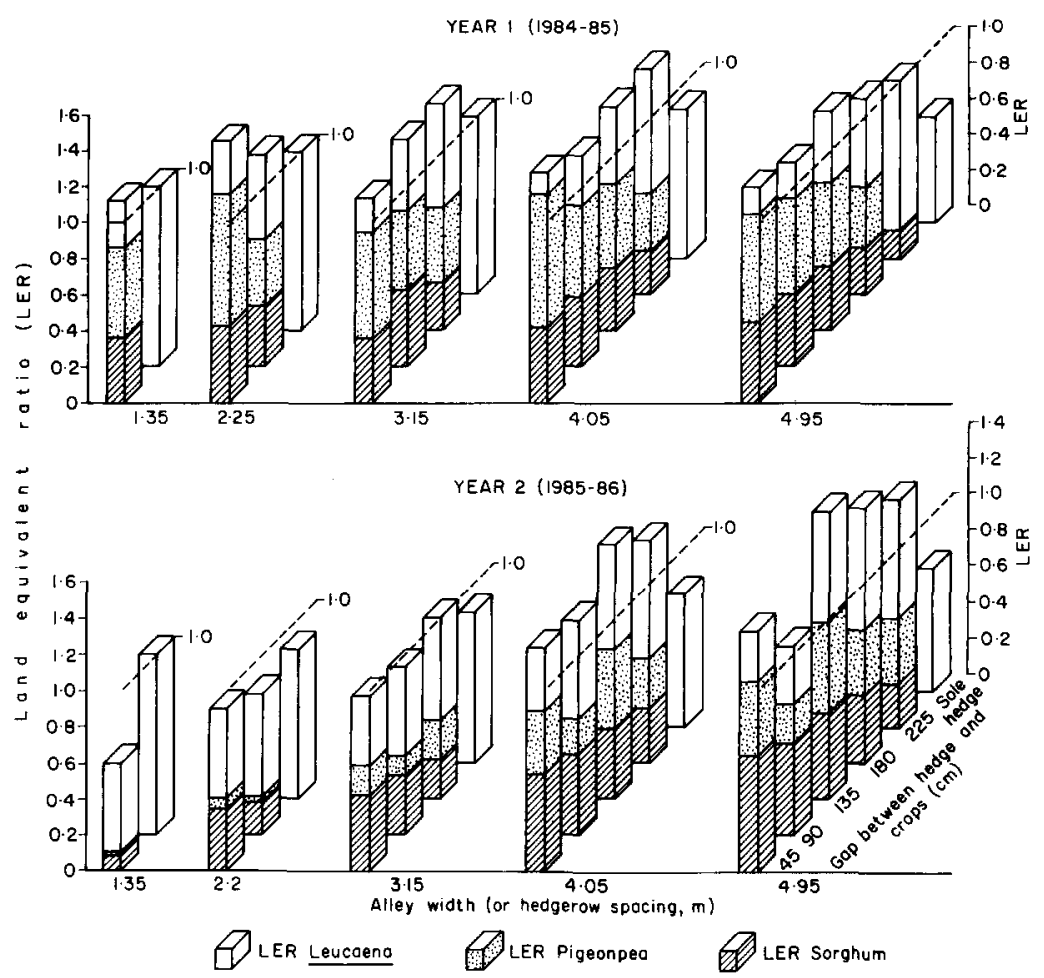

Fig. 4. Land equivalent ratios in the first two years of hedgerow intercropping at ICRISAT Center, Patancheru, India.

those from sole Leucaena and 'sorghum/pigeonpea intercrop control' (Fig. 6). Returns from none of the hedgerow intercrop treatments exceeded those of the most profitable intercrop control in the first two years. Sole Leucaena gave higher returns than intercrop in the third and fourth years. Hedgerow intercrop treatments were still inferior to either of the controls in the third year. Returns were much higher in the fourth year because of the added value of stake wood. Only the 4.05 and $4.95 \mathrm{~m}$ alley width treatments gave higher profits than sole Leucaena by 11 percent and 29 percent respectively. Average returns per year indicated that sorghum/pigeonpea intercrop was still more profitable than sole Leucaena and only the two wider alley width system gave 8 percent and 16 percent higher returns than those of intercrop.

\section{Discussion}

Leucaena became progressively competitive with crops over the years. Consequently, sorghum yield except in the first two years, and pigeonpea 


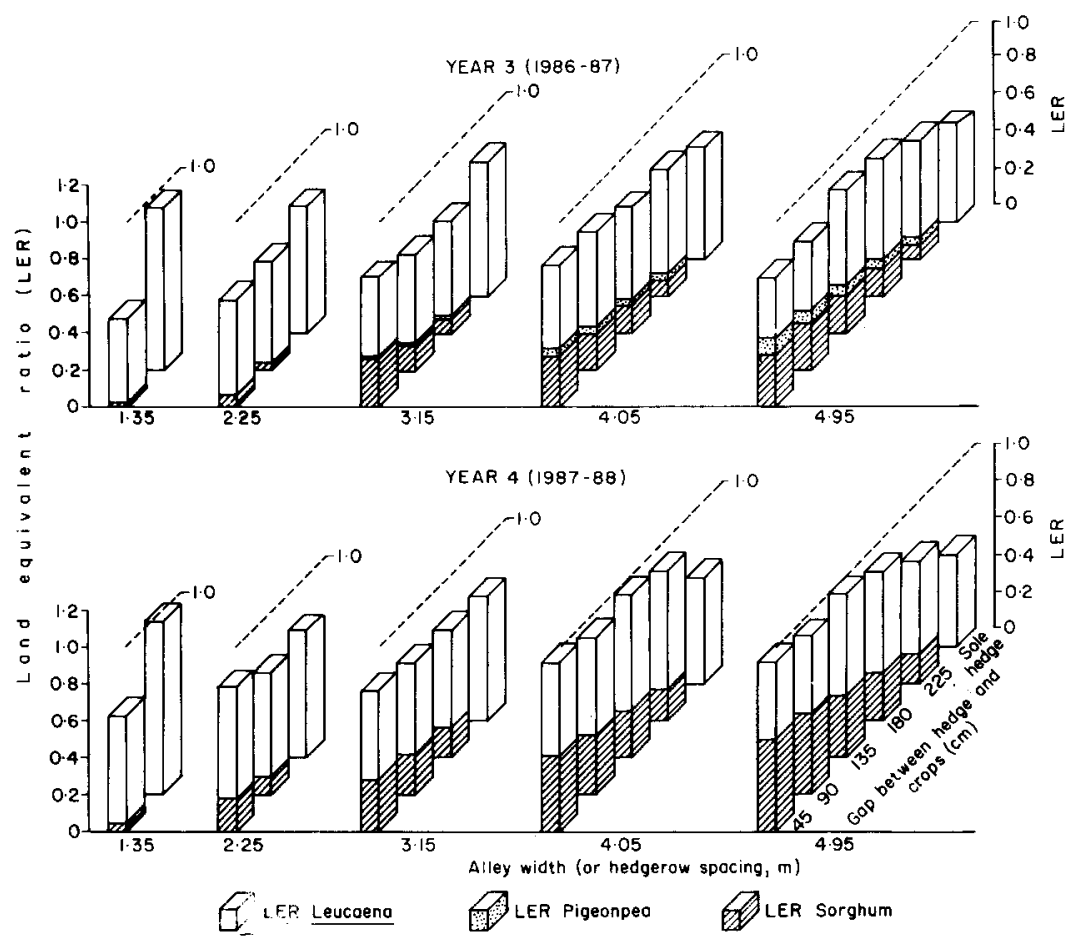

Fig. 5. Land equivalent ratios in the third and fourth year of hedgerow intercropping at ICRISAT Center, Patancheru, India.

yield except in the very first year, were suppressed considerably in hedgerow intercropping. This suppression was not due to the competition for light because the hedges were pruned during the rainy season and also not due to the competition for nutrients because the experimental site was fertilized annually and Leucaena fixes its own nitrogen. The reduction was obviously due to the competition for water. The experimental period was characterized by below normal rainfall. The cropping season particularly in 1985 and 1986 had 30 percent and 17 percent respectively lower than normal rainfall. The moisture stress was particularly severe in the postrainy season causing marked yield reduction in the later-maturing pigeonpea. Leucaena with its well established and extensive root system would utilize more of the limited soil moisture. Thus the greater the proportion of Leucaena in the system (i.e. closer alley width), the stronger was the competition for moisture.

Would the competition be less if single Leucaena rows were used instead of double hedgerows? The authors are not aware of any trial which had compared the effect of planting geometry with Leucaena but numerous intercropping trials with sorghum and pigeonpea did not show any significant effect on final yield. More importantly evidence from an alley 
Table 3. Fodder, yield (dry weight) from Leucaena hedgerows established at different spacings and intercropped with sorghum/pigeonpea over a 4-year period at ICRISAT Center, India

\begin{tabular}{|c|c|c|c|c|c|c|}
\hline \multirow{2}{*}{$\begin{array}{l}\text { Alley width } \\
\text { or hedge } \\
\text { spacing } \\
\text { (m) }\end{array}$} & \multirow{2}{*}{$\begin{array}{l}\text { Gap between } \\
\text { hedge and } \\
\text { crops } \\
\text { (cm) }\end{array}$} & \multicolumn{5}{|c|}{ Leucaena fodder, dry weight } \\
\hline & & $\begin{array}{l}\text { Year } 1 \\
\text { t/ha }\end{array}$ & $\begin{array}{l}\text { Year } 2 \\
\text { t/ha }\end{array}$ & $\begin{array}{l}\text { Year } 3 \\
\text { t/ha }\end{array}$ & $\begin{array}{l}\text { Year } 4 \\
\text { t/ha }\end{array}$ & $\begin{array}{l}\text { Total } \\
\text { t/ha }\end{array}$ \\
\hline 1.35 & 45 & 0.70 & 3.51 & 5.44 & 7.47 & 17.27 \\
\hline \multirow[t]{2}{*}{2.25} & 45 & 0.80 & 3.63 & 5.95 & 7.77 & 18.15 \\
\hline & 90 & 1.29 & 4.12 & 6.40 & 7.15 & 18.96 \\
\hline \multirow[t]{3}{*}{3.15} & 45 & 0.53 & 2.79 & 4.99 & 6.32 & 14.62 \\
\hline & 90 & 0.94 & 3.69 & 5.57 & 6.47 & 16.67 \\
\hline & 135 & 0.61 & 3.96 & 5.87 & 6.81 & 18.25 \\
\hline \multirow[t]{4}{*}{4.05} & 45 & 0.35 & 2.64 & 5.25 & 6.55 & 14.78 \\
\hline & 90 & 0.78 & 4.00 & 5.92 & 6.77 & 17.47 \\
\hline & 135 & 1.16 & 4.19 & 5.81 & 6.82 & 17.98 \\
\hline & 180 & 1.87 & 4.70 & 6.45 & 7.57 & 20.59 \\
\hline \multirow[t]{5}{*}{4.95} & 45 & 0.29 & 2.04 & 3.74 & 5.41 & 11.48 \\
\hline & 90 & 0.45 & 2.31 & 4.31 & 5.39 & 12.46 \\
\hline & 135 & 1.10 & 4.41 & 6.04 & 7.06 & 18.61 \\
\hline & 180 & 1.39 & 4.85 & 6.39 & 7.07 & 19.70 \\
\hline & 225 & 1.58 & 4.82 & 6.07 & 6.54 & 19.00 \\
\hline Sole Leucaena & $(90)$ & 2.79 & 6.52 & 11.56 & 12.83 & 33.70 \\
\hline $\mathrm{SE} \pm$ & & 0.16 & 0.37 & 0.48 & 0.61 & 1.32 \\
\hline
\end{tabular}

cropping trial using a single Leucaena hedgerow in the same region [11] also reported a marked reduction in crop yield. Thus if the population of Leucaena and crops are constant single or double hedgerows are likely to have the same adverse effect on crop yield in semi-arid conditions.

That soil moisture competition was the major cause for reduced yields was evident from the studies of Singh et al. [11] who observed no fall in crop yields when a polythene root barrier was installed to prevent the spread of Leucaena roots to the cropped area. In the absence of such barrier crop yields were only 20 to 40 percent of the sole crops. The better performance of Leucaena in wider alleys and the close relationship between crop yield and the distance from hedge provide a de facto evidence for the spread of Leucaena roots upto $1.8 \mathrm{~m}$ (Fig. 3). Physical examination of Leucaena root system by digging trenches across hedges in a nearby experiment indicated the high concentration of roots in the top $30 \mathrm{~cm}$ of the profile and confirmed their spread into the cropped area [6]. The net effect was low Leucaena yields in the first two years and highly reduced annual crop yields in the later two years making the system less productive than sole crops.

Leucaena yields stabilised at 5 to $6 \mathrm{t} / \mathrm{ha}$ of dry fodder and 2.5 to $3.0 \mathrm{t} / \mathrm{ha}$ 


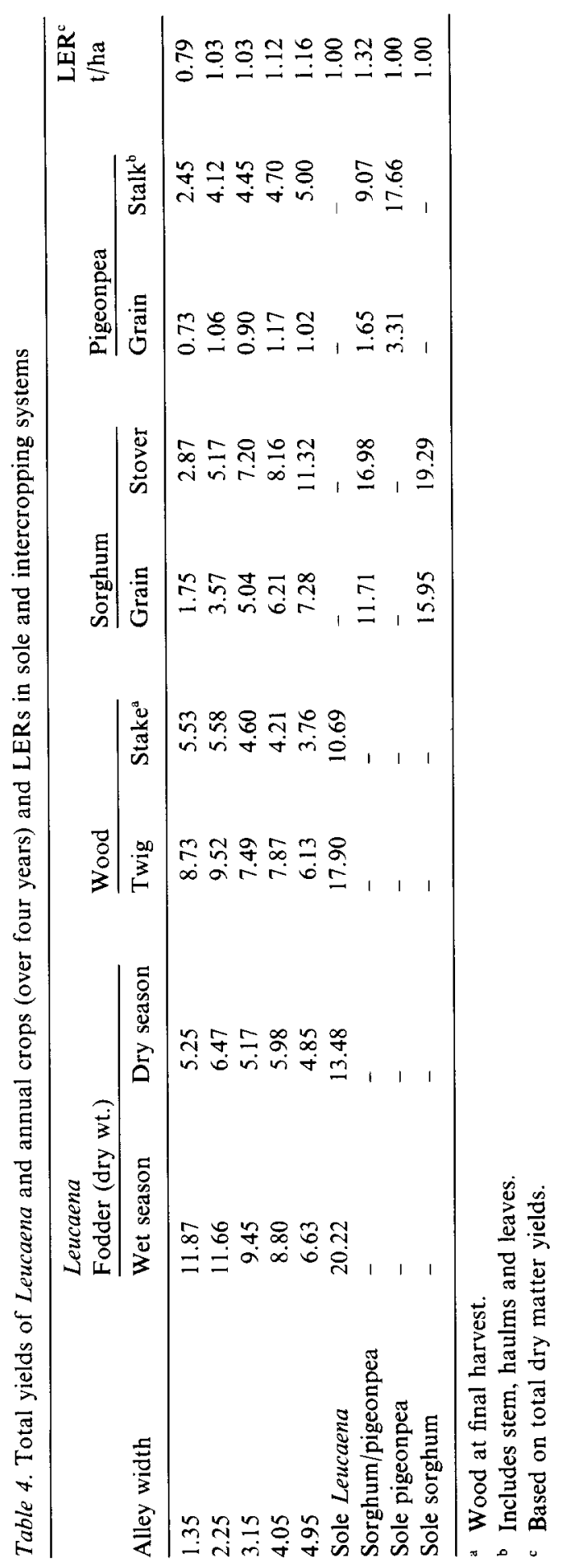



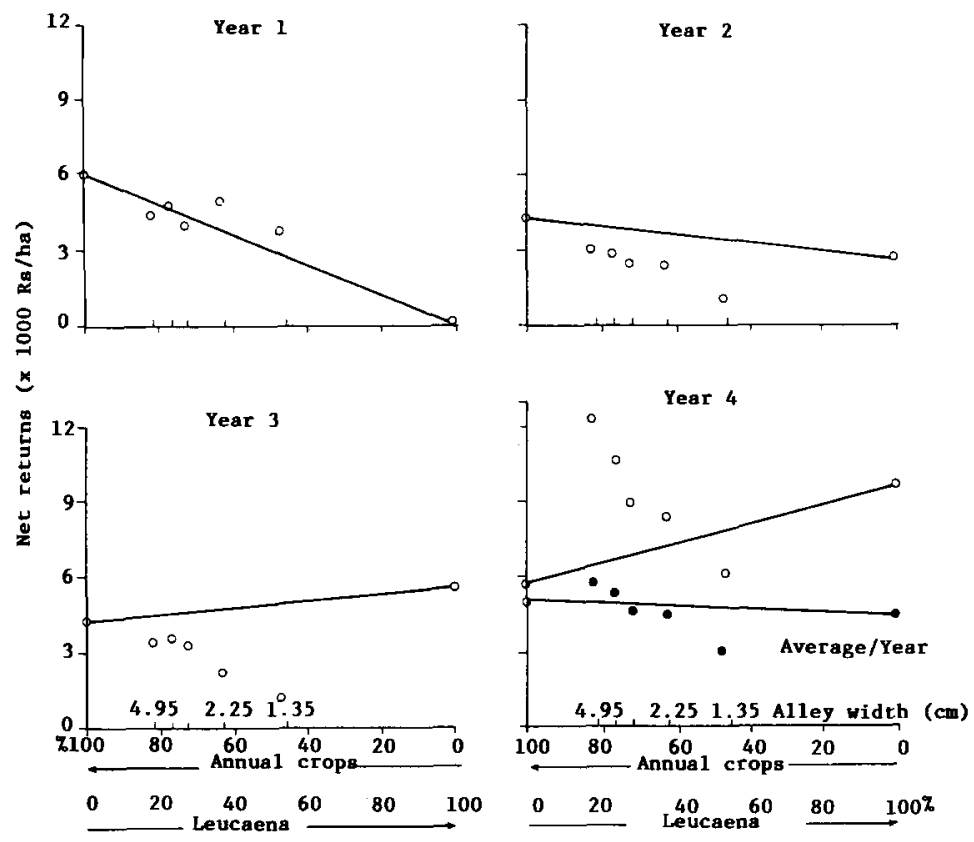

Fig. 6. Net returns from different hedgerow intercropping systems compared with those of sole Leucaena and sorghum/pigeonpea intercrop. Closed symbols refer to average for the four years.

of wood from third year in 4 to $5 \mathrm{~m}$ alleys. In semi-arid tropics farmers' interest in hedgerow intercropping depends on how much extra dry season fodder is produced by the Leucaena with little or no reduction in yield of the annual crops. Dry season (Jan-Jun) growth in wider alleys of the present study was about 40 percent of the total fodder yield. Leucaena fodder in the wet season was not only less valuable because of other sources of fodder supply in this season, but it was produced at a considerable expense to crop yields. Hence hedgerow intercropping with perennials such as Leucaena at alley widths as in the present study is not an attractive proposition for farmers of semi-arid India in $600-700 \mathrm{~mm}$ rainfall areas. The traditional annual crop system of sorghum/pigeonpea intercrop already provides sorghum stover and pigeonpea haulms for livestock and pigeonpea stalks for firewood. It is true that the intercrop does not provide green fodder during the dry season but this can be overcome by allocating the land separately to sole Leucaena. However, the tendency for improved LERs and returns with increasing alley width suggest the need for examining the scope of hedgerow intercropping beyond $5 \mathrm{~m}$ alley widths.

The systematic design provided a range of treatments on a relatively small 
experimental area. The 24 treatments, including 15 hedgerow intercropping, with four replications required only $0.40 \mathrm{ha}$. The design was efficient in respect of net area harvested for yields, which was 50 percent of the total experimental data. In fact, the area harvested from hedgerow treatments was 70 percent of the planted area as all internal hedges (except for some head borders) could be harvested on the premise that adjacent treatments were not very different from one another and hence had little border effects. A conventional design would have required a much larger experimental area because of the need for borders between widely different treatments that might occur together on randomization. Unlike some classic systematic designs such as Nelder fans or geometric designs, this layout provided a reasonable harvest area varying from 10.8 to $33.3 \mathrm{~m}^{2}$ for different treatments as typical of agronomic experiments. Moreover, the systematic arrangement of treatments running in opposite directions between the two replications of a block minimizes the effect of soil variability on treatment performance.

A major limitation of these designs for agroforestry studies is the extensive root system of trees which may interfere with the performance of crops in the neighbouring plots where they are not sufficiently wide apart. In the present study, sole pigeonpea yields bordering sole Leucaena were reduced in the second year due to the spread of Leucaena roots into the pigeonpea plot and the ensuing moisture competition. Nevertheless, this was unlikely to have a major affect on the final outcome of the study. It is possible that the use of intercropped pigeonpea yields for LER calculation might have overestimated the advantage of hedgerow intercropping in the second year.

Systematic designs should be considered for preliminary exploration of a large number of treatments of newly proposed systems at the expense of less experimental resources. Further detailed investigations can then follow with fewer treatments of potential interest together with carefully chosen controls in conventional field-size plots or prototype system trials. The present study, for example, indicated that hedgerow systems with less than 4.0 to $5.0 \mathrm{~m}$ alley widths have little prospects for semi-arid climates. If much wider alley widths (i.e. $>5 \mathrm{~m}$ ) are to be included in the study, the land requirement would have increased considerably which may limit the scope of systematic designs. This also suggests that limited opportunities exist for use of systematic designs on sloping lànds (and highlands) where availability of uniform land is limited and run off might also affect the treatments' performance differently. The balance between statistical/agronomic precision required and experimental resources' availability should determine the relevance of use of systematic designs. 


\section{References}

1. Bleasdale JKA (1967) Systematic designs for spacing experiments. Expl Agric 3: 73-85

2. Brewbaker JL (1987) Leucaena: a multipurpose tree genus for tropical agroforestry. In: Steppler H and Nair PKR (eds), Agroforestry a decade of development. International Council for Research in Agroforestry, Nairobi, Kenya. pp 289-324

3. Huxley PA and Maingu Z (1978) Use of a systematic spacing design as an aid to the study of intercropping: some general considerations. Expl Agric 14: 49-56

4. Huxley PA $\left(1985^{\text {a }}\right)$ The tree/Crop interface - or simplifying the biological/environmental study of mixed cropping agroforestry systems. Agroforestry Systems 3: 251-266

5. Huxley PA (1985 $)$ Systematic designs for field experimentation with multipurpose trees. Agroforestry system 3: 197-207

6. ICRISAT (International Crops Research Institute for the Semi-Arid Tropics), 1986. Annual Report for 1985. ICRISAT, Patancheru PO 502 324, India

7. Kang BT, Grimme H and Lawson TL (1985) Alley cropping sequentially cropped maize and cowpea with Leucaena on a sandy soil in southern Nigeria. Plant and Soil 85: 267-277

8. Nelder JA (1962) New kinds of systematic designs for spacing experiments. Biometrics 18: 283-307

9. Singh RP, van Den Beldt RJ, Hocking D and Korwar GR (1986) Alley cropping in the semi-arid regions of India, presented in 'Alley cropping workshop' held at the International Institute for Tropical Agriculture, Ibadan, Nigeria

10. Willey RW and Rao MR (1981) A systematic design to examine effects of plant population and spatial arrangement in intercropping, illustrated by an experiment on chickpea/ safflower. Exp Agric 17: 63-73

11. Singh RP, Ong CK and Saharan N (1989) Above and below ground interactions in alley-cropping in semi-arid India. Agroforestry Systems 9: 259-274 